\title{
Pengaruh Variasi Kecepatan Pengadukan dengan Penambahan Perlakuan Panas Lapisan Electroless Ni-P terhadap Laju Korosi dan Kekerasan Permukaan Baja Karbon Rendah ASTM A36
}

\author{
Iman Saefuloh $^{1 *}$, Zakaria ${ }^{1}$, Agus Rohmat ${ }^{2}$, Rina Lusiani ${ }^{1}$, Miftahul Jannah ${ }^{1}$, Sunardi $^{1}$, Ipick Setiawan ${ }^{1}$ \\ ${ }^{1}$ Jurusan Teknik Mesin, Fakultas Teknik, Universitas Sultan Ageng Tirtayasa, \\ ${ }^{2}$ Jurusan Teknik Kimia, Fakultas Teknik, Universitas Sultan Ageng Tirtayasa, \\ J1. Jenderal Sudirman km. 3, Cilegon, Banten \\ *E-mail: iman.saefuloh@untirta.ac.id
}

Diterima: 14-07-2021; Direvisi: 26-07-2021; Dipublikasi: 27-08-2021

\begin{abstract}
Abstrak
Tujuan penelitian adalah menganalisa pengaruh kecepatan putar pengadukan dan treatment temperatur proses electroless pada baja karbon rendah ASTM A36 terhadap kualitas lapisan permukaan berdasarkan nilai ketahanan terhadap korosi dan nilai kekerasan serta morfologi permukaan. Penelitian dilakukan dengan memvariasikan. kecepatan pengadukan yang digunakan antara lain 250,300, dan $350 \mathrm{rpm}$, dan proses treatment temperatur 500 sengan waktu 120 menit. Hasil yang diperoleh menunjukkan bahwa kenaikan kecepatan pengadukan menghasilkan ketahanan korosi yang kurang baik dimana laju korosi tertinggi mencapai nilai $7.123 \mathrm{~mm} /$ year. namun nilai ketahanan terhadap korosi semakin membaik ketika diberi perlakuan panas. Nilai laju korosi terendah terdapat pada kecepatan $250 \mathrm{rpm}$ yaitu 1.212 mil/year. Untuk nilai kekerasan dihasilkan hubungan semakin besar kecepatan putaran pengadukan semakin meningkat nilai kekerasannya. Namun bila dibandingkan nilai kekerasan hasil proses perlakuan temperatur dan non perlakuan maka nilai kekerasan terbaik dimiliki oleh proses perlakuan temperatur.
\end{abstract}

Kata kunci: electroles; kecepatan pengadukan; kekerasan; korosi; perlakuan panas

\begin{abstract}
The purpose of this study was to analyze the effect of stirring speed and temperature treatment of the electroless process on ASTM A36 low carbon steel on the quality of the surface layer based on the value of resistance to corrosion and the value of hardness and surface morphology. The research was conducted by varying. The stirring speed used includes 250,300 and $350 \mathrm{rpm}$, and the treatment process temperature is 500 for 120 minutes. The results obtained indicate that an increase in stirring speed results in poor corrosion resistance where the highest corrosion rate reaches a value of 7,123 $\mathrm{mm} /$ year. however, the value of corrosion resistance improved when heat treated. The lowest corrosion rate value is found at a speed of $250 \mathrm{rpm}$, namely 1,212 miles/year. For the value of hardness, the resulting relationship is the greater the stirring rotation speed, the higher the hardness value. However, when compared to the hardness value of the temperature treatment
\end{abstract}

Keywords: electroles; coating time; corrosion; hardness; heat treatment; stirring speed

\section{Pendahuluan}

Plat baja ASTM A36 adalah baja karbon rendah yang memiliki kekuatan yang baik, juga mampu dibentuk menggunakan mesin dan dapat dilas dengan baik. Baja ASTM A36 dapat digunakan untuk berbagai macam aplikasi, tergantung pada ketebalan plat dan ketahanan korosinya. Baja ini sering digunakan pada konstruksi bangunan, tangki, maupun pipa. Karna penggunaannya tersebut, maka diharapkan baja ini mampu memiliki ketahan korosi yang cukup untuk digunakan pada jangka waktu yang lumayan lama. Maka untuk menambah sifat tahan korosi dari baja karbon rendah ASTM A36 ini dapat dilakukan beberapa cara. Salah satunya dengan cara modifikasi permukaan atau yang dikenal dengan coating pada permukaan material baja ASTM A 36 tersebut [1-5].

Metode yang sering digunakan seperti electro plating, metal spraying, vapor deposition (CVD, PVD) dan hot dip. Namun metode-metode tersebut cenderung lebih mahal, maka dipilihlah metode electroless Ni-P yang prosesnya tidak menggunakan listrik dan cenderung lebih terjangkau. Hanya menggunakan media Nickel Phospor sebagai cairan pelapis 
material [6-9]. Pada penelitian sebelumnya yang pernah dilakukan, tentang pengaruh kekasaran permukaan dan kecepatan pengadukan terhadap karakteristik lapisan electroless Ni-P pada baja tahan karat martensitik 420. Penelitian ini menghasilkan semakin kasar permukaan benda uji maka akan menghasilkan daya lekat yang tinggi pula. Dan semakin cepat kecepatan pengadukan menghasilkan ketebalan yang lebih tebal [9]. Namun pada penelitian tersebut kecepatan pengadukan menggunakan kecepatan yang rendah. Pada penelitian sebelumnya pula yang telah dilakukan tentang pengaruh temperatur larutan dan waktu pelapisan elektroles terhadap ketebalan lapisan metal di permukaan plastik ABS. Menghasilkan semakin lama proses pelapisan maka lapisan metal yang terbentuk semakin tebal [10-13]. Juga pada penelitian yang dilakukan tentang pengaruh suhu dan waktu pemanasan terhadap karakteristik lapisan elektroles Ni-P pada baja tahan karat martensitik ss 420 . pada suhu $500^{\circ} \mathrm{C}$ selama 120 menit memiliki nilai korosi yang terbaik [14].

Pada penelitian sebelumnya yang pernah dilakukan Dwi Rahman Rafi dkk (2018) dengan judul Pengaruh Kekasaran Permukaan dan Kecepatan Pengadukan Terhadap Karakteristik Lapisan Electroless Ni-P Pada Baja Tahan Karat Martensitik 420. Pada penelitian ini menggunakan kekasaran permukaan 0,044 $\mu \mathrm{m}, 0,056 \mu \mathrm{m}$, dan 0,164 $\mu \mathrm{m}$ serta dengan variasi kecepatan pengadukan $4,9 \mathrm{rpm}, 11,3 \mathrm{rpm}$, dan 21,3 rpm . Penelitian ini menghasilkan semakin kasar permukaan benda uji maka akan menghasilkan daya lekat yang tinggi pula. Dan semakin cepat kecepatan pengadukan menghasilkan ketebalan lapisan yang lebih tebal. Namun pada penelitian tersebut kecepatan pengadukan menggunakan kecepatan yang rendah. Kemudian pada penelitian sebelumnya pula yang telah dilakukan Nurhakim Bahtiar dkk. (2017) dimana penelitian ini menggunakan variasi waktu pelapisan selama 5, 10, dan 15 menit. Menghasilkan semakin lama proses pelapisan maka lapisan metal yang terbentuk semakin tebal. Pada Penelitian lain juga dijelaskan menggunakan variasi suhu pemanasan $200^{\circ} \mathrm{C}, 300^{\circ} \mathrm{C}, 400^{\circ} \mathrm{C}$, dan $500^{\circ} \mathrm{C}$, sedangkan variasi waktu pemanasan menggunakan 60,120, dan 180 menit. Menghasilkan pada suhu $500^{\circ} \mathrm{C}$ selama 120 menit memiliki nilai laju korosi terendah [14].

Maka pada penelitian kali ini dilakukan penelitian pelapisan baja karbon rendah ASTM A36 dengan metode electroless Ni-P dengan kekasaran permukaan yang tinggi dan ditambah variasi kecepatan pengadukan yang tinggi yaitu $250 \mathrm{rpm}, 300 \mathrm{rpm}$, dan $350 \mathrm{rpm}$ juga waktu pencelupan selama 120 menit kemudian dengan penambahan proses pemanasan pada suhu $500^{\circ} \mathrm{C}$ selama 120 menit.

Tabel 1. Kandungan unsur baja ASTM A36 dengan kandungan yang dominan $\mathrm{Fe}$

\begin{tabular}{|c|c|c|c|}
\hline \multicolumn{4}{|c|}{ Komposisi Kandungan Kimia (\%) } \\
\hline $\mathrm{C}$ & 0.106 & $\mathrm{~V}$ & 0.001 \\
$\mathrm{Si}$ & 0.185 & $\mathrm{Al}$ & 0.024 \\
$\mathrm{Mn}$ & 0.505 & $\mathrm{Ti}$ & 0.001 \\
$\mathrm{P}$ & 0.009 & $\mathrm{~N}$ & 0.053 \\
$\mathrm{~S}$ & 0.004 & $\mathrm{Ce}$ & 0.21 \\
$\mathrm{Nb}$ & 0.002 & $\mathrm{Ni}$ & 0.046 \\
$\mathrm{Cu}$ & 0.014 & $\mathrm{Mo}$ & 0.009 \\
$\mathrm{Cr}$ & 0.093 & & \\
\hline
\end{tabular}

\section{Material dan metodologi}

\subsection{Preparasi sampel}

Hal pertama yang dilakukan adalah memotong baja ASTM A 36 dengan dimensi $2 \times 3 \mathrm{~cm}$ menggunakan gerinda potong. Kemudian menghilangkan sisa pemotongan dan karat yang terlihat dengan gerinda tangan. Setelah bersih sampel permukaan diamplas menggunakan amplas grid 400. Setelah permukaan sampel bersih barulah dicuci menggunakan deterjen untuk menghilangkan lemak yang terdapat pada baja. Lalu sampel dicelupkan kedalam cairan 
Iman Saefuloh dkk /Jurnal Rekayasa Mesin

p-ISSN: 1411-6863, e-ISSN: 2540-7678

Vol.16, No.2, Agustus 2021, hal. 241-248

kimia kimia HNO $10 \mathrm{ml}+20 \mathrm{ml} \mathrm{HCL}+30 \mathrm{ml}$ aquades selama 2 menit guna lebih membersihkan permukaan dan mempersiapkan permukaan untuk pelapisan. Setelah itu sampel dibilang dengan air aquades selama 2 menit.

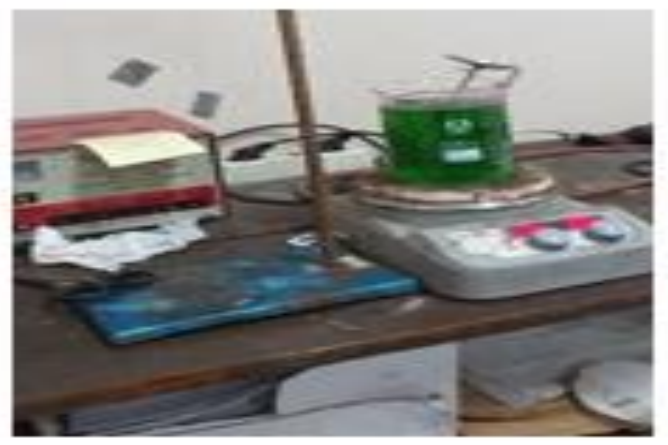

Gambar 1. Preparasi sampel metode ASTM A36 (Laboratorium Kimia Untirta)

\subsection{Menyiapkan larutan electroless}

Larutan electroless dibuat dengan mencampurkan sejumlah bahan yang dicampur kedalam gelas berisi $500 \mathrm{ml}$ aquades, dengan komposisi:

- Nickel Sulfat $35 \mathrm{~g} / \mathrm{l}$ jika dibuat $500 \mathrm{ml}$ maka 17,5 gr

- Sodium Hipoposfit $20 \mathrm{~g} / \mathrm{l}$ jika dibuat $500 \mathrm{ml}$ maka $10 \mathrm{gr}$

- Sodium Acetit $5 \mathrm{~g} / \mathrm{l}$ jika dibuat $500 \mathrm{ml}$ maka 2,5 gr

- Sodium Citrat $15 \mathrm{~g} / \mathrm{l}$ jika dibuat $500 \mathrm{ml}$ maka 7,5 gr

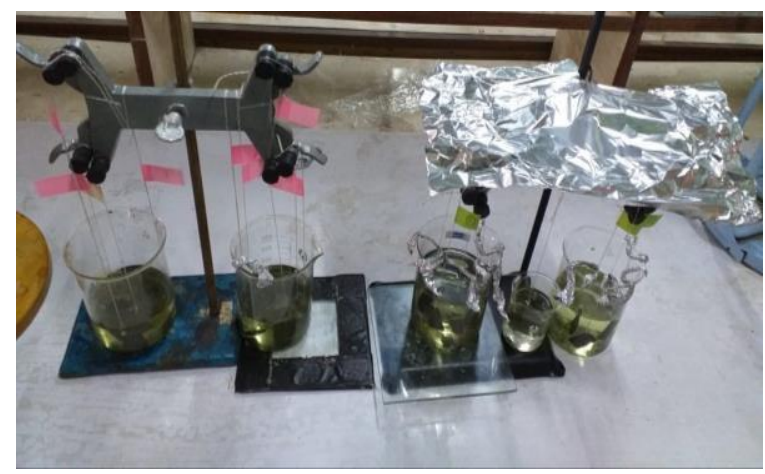

Gambar 2. Pencampuran beberapa senyawa larutan electroless kedalam gelas/tabung reaktor (Lab Kimia Untirta)

\subsection{Proses perendaman}

Sebelum proses perendaman dimulai, pastikan terlebih dahulu larutan electroless sudah berada pada suhu $\pm 80^{\circ} \mathrm{C}$ dan memiliki PH 4-5. Setelah itu sampel diikatkan pada tiang statis diatas gelas perendaman. Proses perendaman dilakukan dengan variasi kecepatan pengadukan dan waktu pencelupan yang berbeda. Tabel 2 menunjukkan perbedaan variasi perlakuan sampel selama proses perendaman berlangsung.

Tabel 2. Variasi Proses perendaman

\begin{tabular}{|c|c|c|}
\hline Sampel & $\begin{array}{c}\text { Kecepatan Pengadukan } \\
\text { (RPM) }\end{array}$ & $\begin{array}{c}\text { Waktu Pelapisan } \\
\text { (Menit) }\end{array}$ \\
\hline 1 & 250 & 120 \\
2 & 300 & 120 \\
3 & 350 & 120 \\
\hline
\end{tabular}




\subsection{Proses pemanasan (Heat treatment)}

Setelah proses perendaman, sampel dipanaskan pada oven pemanas dengan suhu $500^{\circ} \mathrm{C}$ selama 120 menit. Proses ini bertujuan untuk lebih merekatkan lapisan.

\section{Hasil dan pembahasan}

\subsection{Analisa Laju Korosi Hasil Lapisan Electroless Ni-P}

Analisis uji korosi digunakan untuk mengetahui seberapa kuat lapisan terhadap korosi yang terjadi. Pengujian ini dilakukan dengan menggunakan metode kehilangan berat yang mengacu pada ASTM G 31. Pengujian dilakukan dengan melakukan perendaman sampel pada media larutan HCL 10\% selama 24 jam. Berat sampel akan ditimbang terlebih dahulu sebelum dan sesudah terjadinya perendaman, kemudian selisih beratnya dihitung dan didapat nilai laju korosi. Dari grafik diatas pula dapat dilihat hasil laju korosi terendah terdapat pada kecepatan pengadukan 250 rpm, kemudian $300 \mathrm{rpm}$, dan terakhir $350 \mathrm{rpm}$. Ini menunjukkan bahwa semakin rendah kecepatan pengadukan yang terjadi maka nilai laju korosi yang terjadi semakin rendah. Dan semakin cepat kecepatan pengadukan yang terjadi menghasilkan nilai laju korosi yang semakin besar.

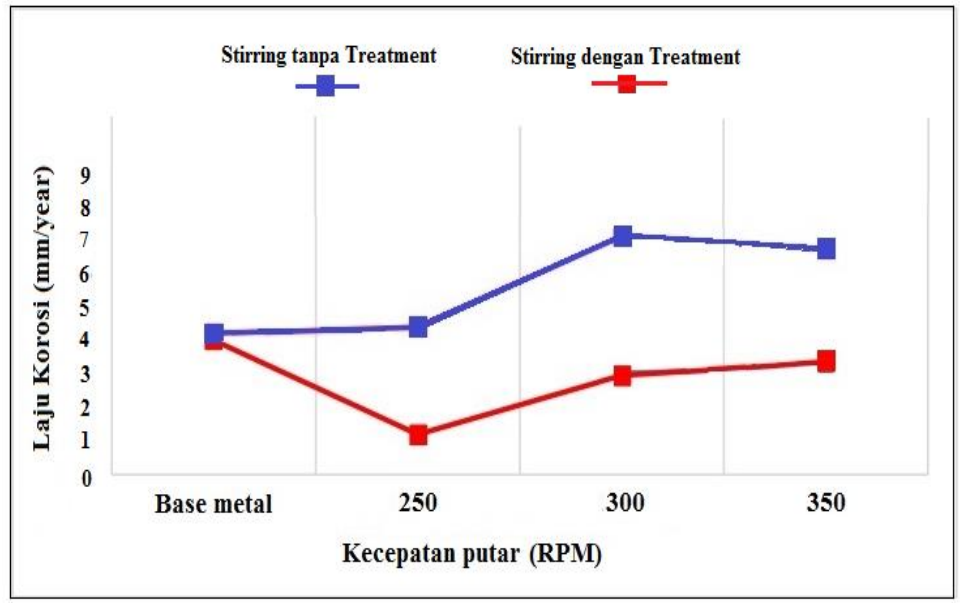

Gambar 3. Grafik hubungan nilai laju korosi terhadap kecepatan pengadukan.

Pada Gambar 3 terlihat perbedaan nilai laju korosi yang tidak melalui proses pemanasan dan sampel yang melalui proses pemanasan setelah proses pelapisan dilakukan. Nilai laju korosi setelah proses pemanasan mempunyai nilai yang lebih baik daripada sampel yang tidak dilapisi dan sampel yang tidak melalui proses pemanasan setelah proses pelapisan. Perbedaan variasi kecepatan pengadukan yang diberikan dapat dilihat bahwa kecepatan 250 rpm mempunyai hasil yang terbaik, kemudian diikuti pada kecepatan $300 \mathrm{rpm}$ dan terakhir pada kecepatan 350 rpm. Maka semakin cepat putaran pengadukan maka hasil yang didapatkan semakin buruk, dan semakin rendah putaran pengadukan mempunyai nilai laju korosi yang lebih baik.

\subsection{Analisis Uji Kekerasan}

Analisis uji kekerasan dilakukan untuk mengetahui sifat mekanik berupa nilai kekerasan dari baja yang telah dilapisi. Pengujian ini menggunakan metode Rockwell dengan standar JIS Z 2245 (2016) yang dilakukan di PT. Krakatau Steel. Pegujian mencakup sampel yang melalui proses pemanasan dan yang tidak melalui proses pemanasan. kenaikan pada nilai kekerasannya. Namun pengaruh dari proses pelapisan electroless Ni-P ini tidak berpengaruh secara signifikan pada nilai kekerasan dari baja ASTM A36 tersebut. 
Iman Saefuloh dkk /Jurnal Rekayasa Mesin p-ISSN: 1411-6863, e-ISSN: 2540-7678

Vol.16, No.2, Agustus 2021, hal. 241-248

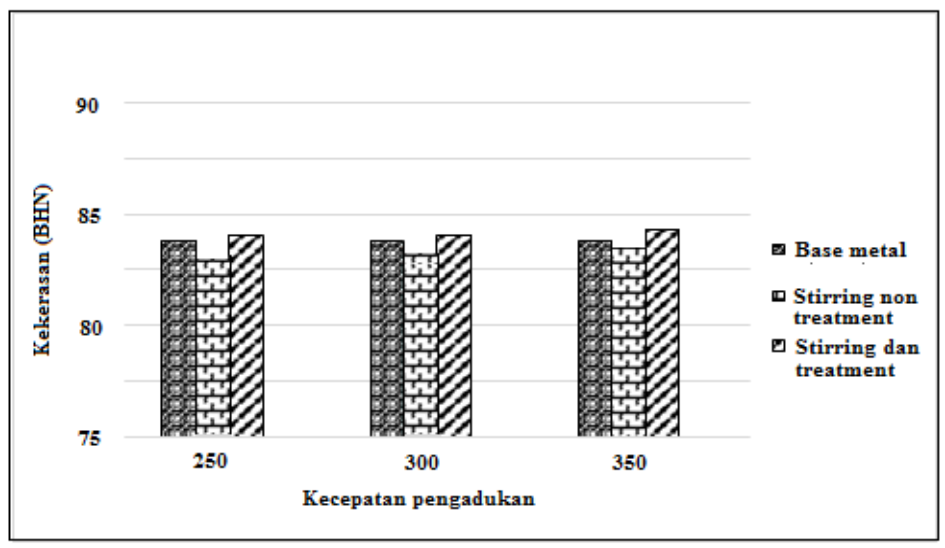

Gambar 4. Grafik hubungan nilai kekerasan terhadap kecepatan proses pengadukan

Pada Gambar 4 dapat dilihat bahwa perbedaan kecepatan pengadukan tidak mempengaruhi nilai kekerasan dari baja ASTM A 36. Karena pada dasarnya proses pelapisan electroless Ni-P ini tidak mempengaruhi nilai dari kekerasan baja tersebut. Pada gambar grafik diatas dapat dilihat bahwa variasi waktu perendaman pada proses pelapisan electroless Ni-P tidak berpengaruh signifikan pada hasil kekerasan baja ASTM A 36. Karna pada dasarnya lapisan electroless tersebut tidak merubah sifat mekanik kekerasan pada baja yang dilapisi.

\subsection{Analisa Morfologi dan komposisi Hasil Lapisan Electroless Ni-P}

Analisis permukaan hasil pelapisan electroless Ni-P dengan menggunakan Scanning electron microscopy energy dispersive spectrometry (SEM EDS). Untuk mengetahui struktur lapisan yang terbentuk dari hasil pelapisan. Sampel yang diuji adalah varian dengan kecepatan putaran $250 \mathrm{rpm}, 300 \mathrm{rpm}$ dan 350 pada waktu pencelupan 120 menit sebelum dan sesudah dilkukan perlakuan temperatur [12].

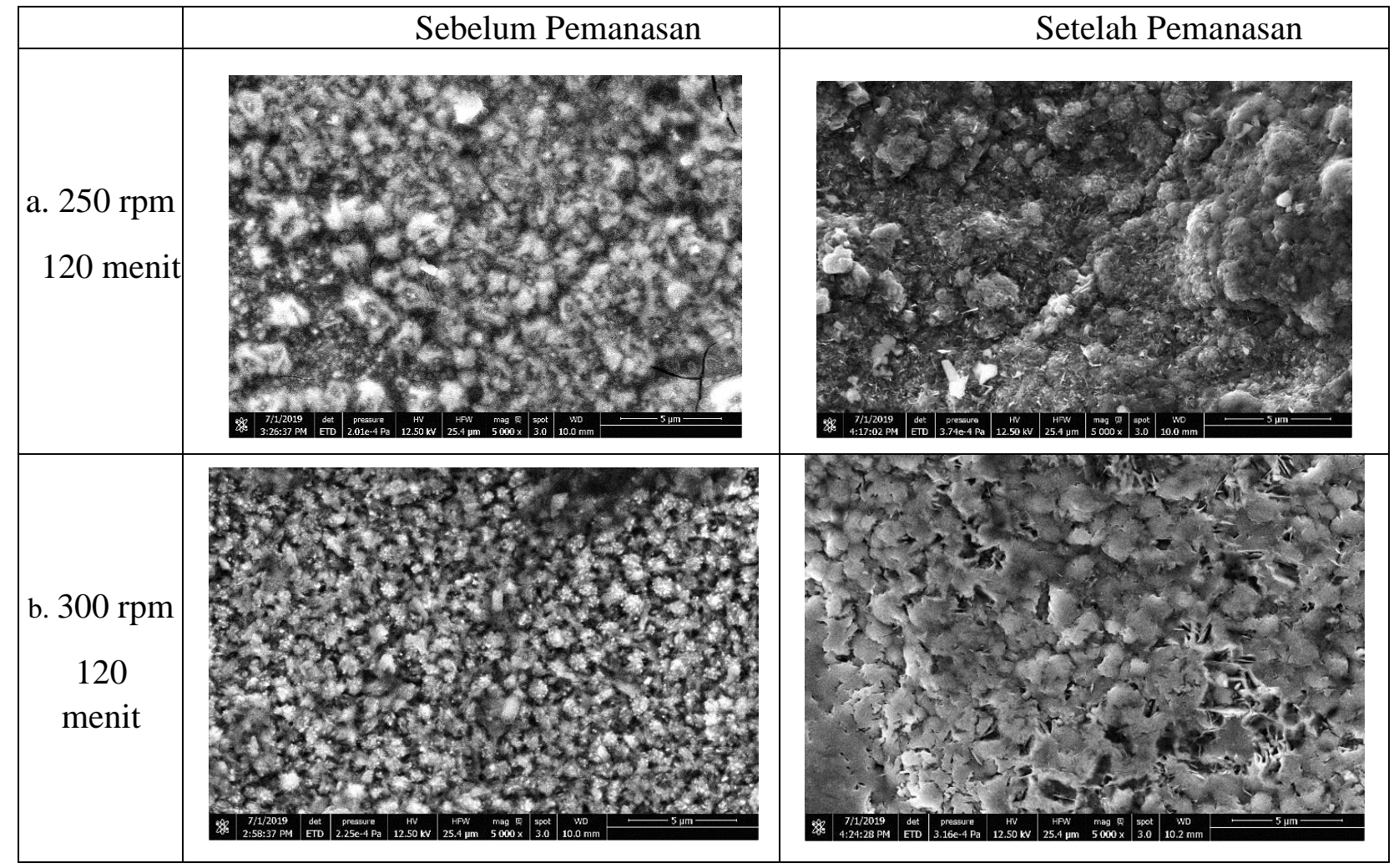




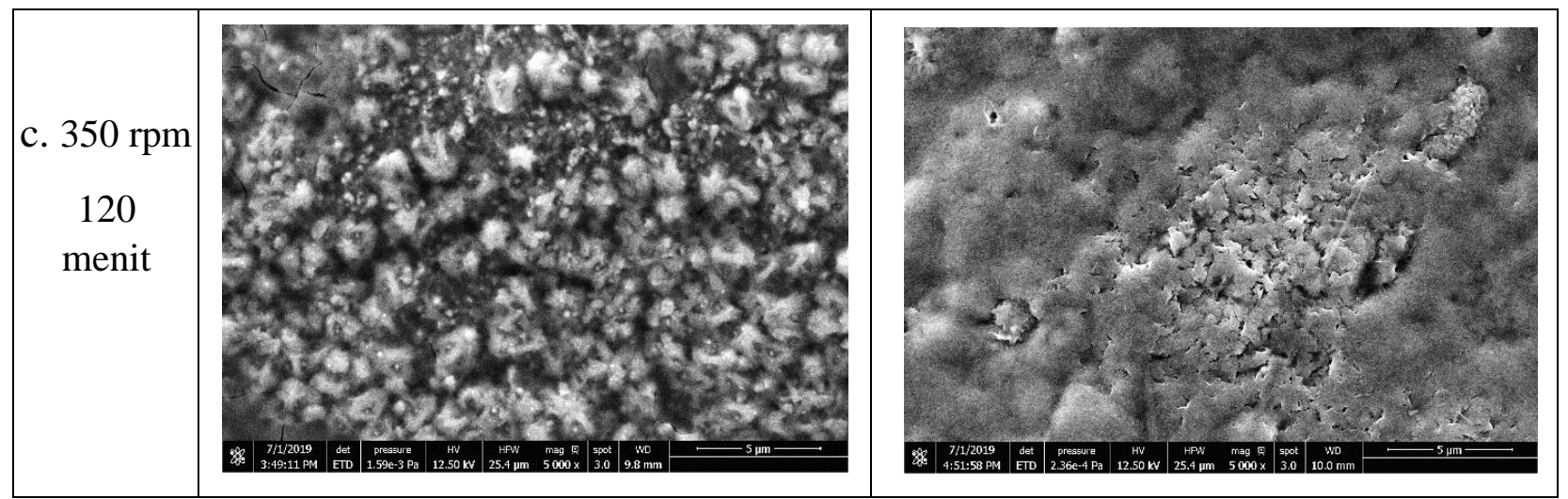

Gambar 5. Hasil SEM dengan perbesaran 1000x dengan kecepatan putar dan waktu electroless a. 250rpm, 120 menit b. 300rpm,120menit c. 350rpm, 120menit

Pada hasil pengujian SEM EDS terdapat pula komposisi unsur pada lapisan yang terkandung. Pada lapisan ini terdapat berbagai unsur seperti carbon, oksigen, natrium, sulfur, besi, dan nikel. Namun unsur yang paling banyak adalah nikel dan sulfur. Data komposisi unsur setiap sampel ini dapat dilihat masing-masing pada tabel dibawah ini.

Hasil ketebalan lapisan dipeloreh dari sampel dengan varian $250 \mathrm{rpm}$ pada waktu pencelupan 120 menit yang mengalami pemanasan setelah pelapisan pada suhu $500^{\circ} \mathrm{C}$ selama 120 menit. Hasil ketebalan lapisan memiliki ketebalan rata - rata setebal 22,93 $\mu \mathrm{m}$. Sehingga dapat diasumsikan ketebalan lapisan pada sampel lain tidak jauh berbeda [15].

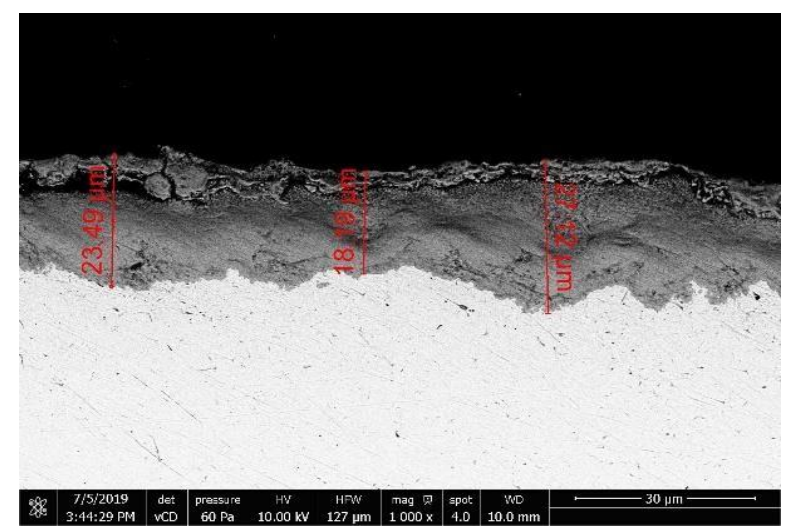

Gambar 6. Ketebalan hasil proses elektroless pada kecepatan pengadukan 250 dan waktu 120 menit

Dari Gambar 6 dapat dilihat bahwa pada variasi kecpatan $250 \mathrm{rpm}$ selama 120 menit sebelum dan setelah proses pemanasan memiliki butir struktur yang paling kecil dan merata. Lalu pada struktur lapisan yang telah melawati proses pemanasan memilik struktur yang kecil dan rapat. Kemudian pada variasi 300 rpm selama 120 menit sebelum dan setelah proses pemanasan memilik butir struktur yang lebih besar. Juga pada stuktur yang telah melewati proses pemanasan memiliki struktur yang lebih rapat ketimbang sebelum proses pemanasan.

Maka dapat dilihat unsur nickel yang paling besar pada sebelum dan setelah proses pemanasan terkandung pada variasi $250 \mathrm{rpm}$ selama $300 \mathrm{rpm}$ kemudian selama $350 \mathrm{rpm}$. Terlihat bahwa semakin tinggi kecepatan pengadukan maka kandungan nickel akan semakin banyak. Namun pada kecepatan $350 \mathrm{rpm}$ sudah tidak efisien dan justru terjadi penggerusan karna terlalu cepat proses pelapisan. 


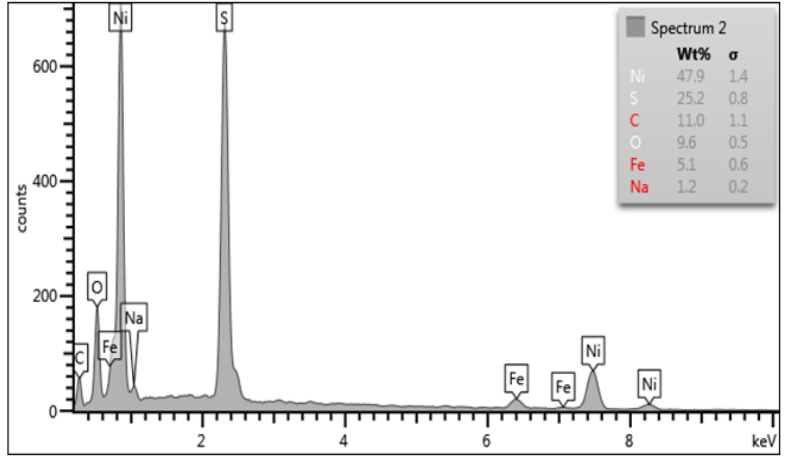

(a)

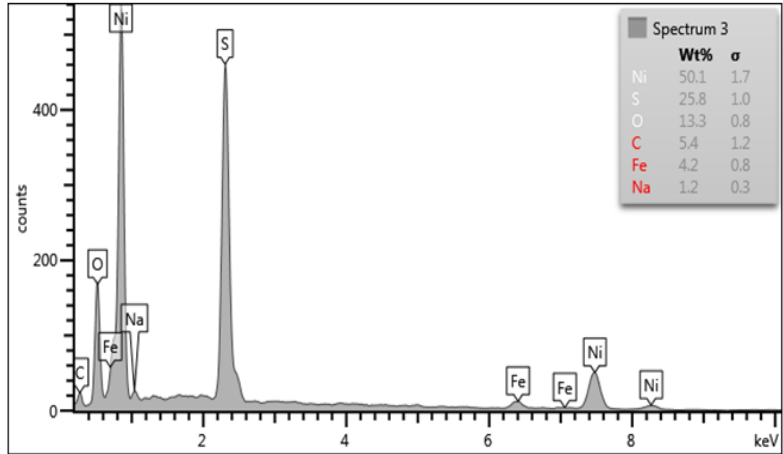

(b)

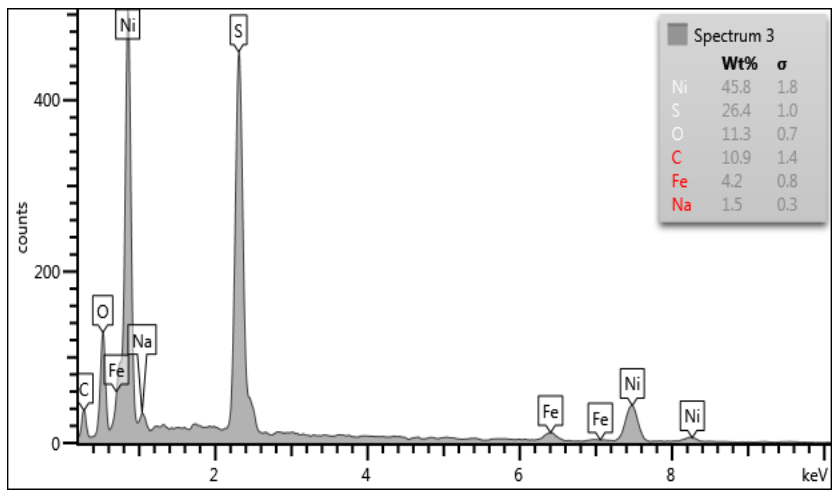

(c)

Gambar 7. Hasil SEM-EDS dengan kecepatan putar dan waktu electroless a. 250rpm, 120 menit b. 300rpm,120menit c. 350rpm, 120menit

Pada Gambar 7 dari hasil SEM-EDS ini bisa dilihat bahwa lapisan yang mengandung unsur nickel lebih banyak memiliki nilai laju korosi yang lebih rendah. Namun adanya proses pemanasan setelah pelapisan membuat lapisan yang terbentuk lebih rapat sehingga walaupun kandngan nickel-nya tidak berbeda jauh dengan sampel yang tidak melalui proses pemanasan, nilai korosinya tetap lebih baik.

\section{Kesimpulan}

Berdasarkan penelitian analisa maka dapat disimpulkan:

Kecepatan pengadukan pada proses electroless sangat berpengaruh terhadap kualitas lapisan bahwa kenaikan kecepatan pengadukan menghasilkan ketahanan korosi yang semakin baik. Nilai laju korosi terendah terdapat pada kecepatan 250 rpm, diikuti $300 \mathrm{rpm}$ kemudian $350 \mathrm{rpm}$. Demikian pula proses perlakuan temperatur pada suhu $500^{\circ} \mathrm{C}$ selama 120 menit sangat berpengaruh besar terhadap kualitas lapisan hasil electroless dimana dapat meningkatkan nilai ketahanan korosi dan nilai kekerasan.

\section{Daftar Pustaka}

[1] Fontana, GM. 1987. “Corrosing engineering” $3^{\text {rd }}$. New York: McGraw - Hill Book Company.

[2] Ron P. 2015. "Properties and application electroless nickel." Amerika Serikat. Nickel development institute.

[3] Wahudi, S. 2012. "Buku Saku Elektroplating." 1-44.

[4] Takei T , 1998. Surface Finishing Handbook, edited by Metal Finishing Soc. Japan, Nikkan Kogyo Shimbun Co., pp. 283-295.

[5] Equbal, A, and K. A.Sood. 2014."Metallization on FDM Parts Using the Chemical Deposition Technique.” Coatings 4 (3): 574-586. 
[6] Mabruri Efendi, dkk. 2015. Pengaruh Mo dan Ni terhadap struktur mikro dan kekerasan baja tahan karat martensitik 13Cr. Majalah Metalurgi 3 : 133-140. Pusat Penelitian Metalurgi dan Material - LIPI Gedung 470 Kawasan Puspitek. Tangerang Selatan. Indonesia.

[7] Lestari Yulinda, Mabruri Efendi, dkk. 2016. Studi pelapisan komposit Ni-P-Nano $\mathrm{AL}_{2} \mathrm{O}_{3}$ dengan metode electroless co-doposition. Jurnal Material Metalurgi (2016) 1: 1-68.

[8] Taheri, R. (2002). Evaluation of Electroless Nickel-Phosphorus (EN) Coatings. Journal University of Saskatchewan

[9] Dwi Rachman Rafi, Nikitasari Arini, dkk. 2018. Pengaruh Kekasaran Permukaan Dan Kecepatan Pengadukan Terhadap Karakteristik Lapisan Elektroles Ni-P Pada Baja Tahan Karat Martensitik SS 420. Widyasari. Vol. 4 No.1.

[10] Santhiarsa, Nitya. 2016. Pengaruh Temperatur Larutan dan Waktu Pelapisan Elektroles Terhadap Ketebalan Lapisan Metal Di Permukaan Plastik ABS. Prosiding Konferensi Nasional Engineering Perhotelan VII.

[11] Santhiarsa, N. 2016. "Pengaruh Temperatur Larutan dan Waktu Pelapisan Elektroles Terhadap Ketebalan Lapisan Metal Dipermukaan Plastik ABS.” Prosiding Konferensi Nasional Engineering Perhotelan VII 4 (1): 22

[12] Tang, X.,M.Cao, C Bi, L Yan, and B. Zhang. 2007. “A new palladium-free surface act ivation process for Ni electroless plating on ABS plastic." Materials Letters (63): 840-842.

[13] Wang, G. X, N. Li, H.L.Hu, and Y.C.Yu. 2006. "Process of Direct Copper Plating on ABS Plastics." Applied Surface Science 253 (2): 480-484.

[14] Nurhakim Bahtiar, Nikitasari Arini, dkk. 2017. Pengaruh Suhu Dan Waktu Pemanasan Terhadap Karakteristik Lapisan Elektroles Ni-P Pada Baja Tahan Karat Martensitik SS 420. Jurnal Sains Materi Indonesia. ISSN : 1411-1098.

[15] Goodge John, Energy-Disperive X-Ray Spectroscopy (EDS), Integrating Research and Education, University of Minnesota-Duluth. 